\title{
Haloterrigena longa sp. nov. and Haloterrigena limicola sp. nov., extremely halophilic archaea isolated from a salt lake
}

\author{
Correspondence \\ Shuang-Jiang Liu \\ shuangjiang@hotmail.com
}

\author{
Heng-Lin Cui, ${ }^{1,2}$ Dilbr Tohty, ${ }^{3}$ Pei-Jin Zhou ${ }^{1}$ and Shuang-Jiang Liu ${ }^{1}$ \\ ${ }^{1}$ State Key Laboratory of Microbial Resources, Institute of Microbiology, Chinese Academy of \\ Sciences, Beijing 100080, People's Republic of China \\ ${ }^{2}$ Graduate University of Chinese Academy of Sciences, Beijing 100049, \\ People's Republic of China \\ ${ }^{3}$ College of Life Sciences, Xin-Jiang Normal University, Urumqi 830053 , \\ People's Republic of China
}

Halophilic archaeal strains $\mathrm{ABH} 32^{\top}$ and $\mathrm{AX}-7^{\top}$ were isolated from Aibi salt lake in Xin-Jiang, China, and were subjected to taxonomic studies. The cells of both strains were rod-shaped, and growth required at least $10 \%(\mathrm{w} / \mathrm{v}) \mathrm{NaCl}$. The cellular polar lipids were identified as phosphatidylglycerol, phosphatidylglycerol phosphate methyl ester and mannose-2,6-disulfate $(1 \rightarrow 2)$-glucose glycerol diether $\left(S_{2}-D G D\right)$. The isolates were different in that strain $\mathrm{ABH} 32^{\top}$ did not require magnesium and had strong ability to assimilate sugars for growth, whereas strain $A X-7^{\top}$ required magnesium and did not assimilate glucose, sucrose or maltose for growth. Both strain $\mathrm{ABH} 32^{\top}$ and strain $\mathrm{AX}-7^{\top}$ were most closely related to members of the genera Haloterrigena and Natrinema. On the basis of phenotypic and genotypic characteristics, especially their cellular polar lipids, the two isolates were assigned to the genus Haloterrigena. Moreover, the DNA relatedness values for strains $A B H 32^{\top}$ and $A X-7^{\top}$ with respect to members of the genus Haloterrigena were found to be well below $70 \%$. Thus, strains $A B H 32^{\top}$ and $A X-7^{\top}$ represent two novel species within the genus Haloterrigena, for which the names Haloterrigena longa sp. nov. (type strain $\mathrm{ABH} 32^{\top}=\mathrm{CGMCC} 1.5334^{\top}=\mathrm{JCM} 13562^{\top}$ ) and Haloterrigena limicola sp. nov. (type strain $A X-7^{\top}=C G M C C 1.5333^{\top}=J C M 13563^{\top}$ ) are proposed.
On the basis of phylogenetic analysis and DNA-DNA hybridization data, the genus Haloterrigena was established by Ventosa et al. (1999) as accommodating a single species, Haloterrigena turkmenica. Haloterrigena thermotolerans (Montalvo-Rodríguez et al., 2000) and Haloterrigena saccharevitans (Xu et al., 2005) were described subsequently. In phylogenetic trees based on 16S rRNA gene sequences, species of the genera Haloterrigena and Natrinema sometimes cluster together (Montalvo-Rodríguez et al., 2000; Xin et al., 2000; Tindall, 2003) depending on the selection of sequences used. However, there are differences in the polar lipid composition among species of these two genera. All type strains of the species of Haloterrigena possess mannose2,6 -disulfate $(1 \rightarrow 2)$-glucose glycerol diether $\left(S_{2}\right.$-DGD), but

Abbreviation: $S_{2}$-DGD, mannose-2,6-disulfate $(1 \rightarrow 2)$-glucose glycerol diether.

The GenBank/EMBL/DDBJ accession numbers for the 16S rRNA gene sequences of strains $A B H 32^{\top}$ and $A X-7^{\top}$ are $D 0367242$ and D0367241, respectively.

Thin-layer chromatograms showing the polar lipids of strains $A B H 32^{\top}$ and $A X-7^{\top}$ are available as supplementary figures in IJSEM Online. lack phosphatidylglycerol sulfate (or contain levels below the limit of detection) (Ventosa et al., 1999; MontalvoRodríguez et al., 2000). The opposite is true for the species of Natrinema (McGenity et al., 1998; Xin et al., 2000), and two strains of Htg. turkmenica, JCM 9743 and strain GSL-11, have been shown to possess glycolipids other than $S_{2}$-DGD (Ventosa et al., 1999). Thus, on the basis of a combination of phylogenetic, morphological and chemotaxonomic characteristics, the currently described species (represented by their type strains) of these genera can be distinguished from each other. During our surveys on the biodiversity of the halophilic archaea of Aibi salt lake in the Xin-Jiang region of China (Cui et al., 2006), we obtained two strains that showed the same polar lipid pattern as that of members of the genus Haloterrigena. In this paper, we describe the characterization and the taxonomy of the two strains, $\mathrm{ABH} 32^{\mathrm{T}}$ and strain $\mathrm{AX}-7^{\mathrm{T}}$. The results indicated that these two stains represent two novel species of the genus Haloterrigena.

Strain $\mathrm{ABH} 32^{\mathrm{T}}$ and strain $\mathrm{AX}-7^{\mathrm{T}}$ were isolated from sediment of Aibi salt lake. The isolation procedure was 
the same as that described previously (Xin et al., 2000; Feng et al., 2004, 2005; Xu et al., 2005). The characterization of strains $\mathrm{ABH} 32^{\mathrm{T}}$ and $\mathrm{AX}-7^{\mathrm{T}}$ was performed according to the minimal standards proposed for the description of novel taxa of the order Halobacteriales (Oren et al., 1997). Morphological observation, growth characteristic tests, miscellaneous biochemical tests, nutrition tests, sensitivity to antimicrobial agents, lipid analysis and nucleic acid characterization were performed as described or cited by Xu et al. (2005).

The cells of strains $\mathrm{ABH} 32^{\mathrm{T}}$ and $\mathrm{AX}-\mathrm{7}^{\mathrm{T}}$ are rods, Gramnegative and able to grow in a wide range of salinities $(1 \cdot 7-5 \cdot 1 \mathrm{M} \mathrm{NaCl})$. Colonies on agar medium are redpigmented. Strain $\mathrm{ABH} 32^{\mathrm{T}}$ is different from strain $\mathrm{AX}-7^{\mathrm{T}}$ in that the former does not require magnesium, is unable to reduce nitrate and is able to assimilate sugars (glucose, sucrose and maltose). Detailed results of morphological analyses, assessments of growth characteristics, nutritional experiments, antibiotic-sensitivity determinations and miscellaneous biochemical tests conducted with strains $\mathrm{ABH} 32^{\mathrm{T}}$ and $\mathrm{AX}-7^{\mathrm{T}}$ are given in the species descriptions. The physiological and biochemical differences among strain

Table 1. Characteristics that distinguish strains $A B H 32^{\top}$ and $A X-7^{\top}$ from other members of the genus Haloterrigena

Strains: 1, strain $\mathrm{ABH} 32^{\mathrm{T}} ; 2$, strain $\mathrm{AX}-7^{\mathrm{T}} ; 3$, Htg. turkmenica JCM $8891^{\mathrm{T}}$ (data from Zvyagintseva \& Tarasov, 1987; Ventosa et al., 1999); 4, Htg. thermotolerans CGMCC $1.3709^{\mathrm{T}}$ (MontalvoRodríguez et al., 2000); 5, Htg. saccharevitans CGMCC $1.3730^{\mathrm{T}}$ (Xu et al., 2005). +, Positive; -, negative; W, weak; ND, no data available.

\begin{tabular}{|c|c|c|c|c|c|}
\hline Characteristic & 1 & 2 & 3 & 4 & 5 \\
\hline Cell shape & Rod & Rod & Coccoid & Rod & Rod \\
\hline Motility & - & + & - & - & + \\
\hline $\mathrm{Mg}^{2+}$ requirement & - & + & ND & - & - \\
\hline $\mathrm{H}_{2} \mathrm{~S}$ formation & + & + & - & ND & + \\
\hline Nitrate reduction & - & + & + & + & + \\
\hline Indole formation & + & - & - & - & - \\
\hline \multicolumn{6}{|l|}{ Hydrolysis of: } \\
\hline Tween 20 & + & + & ND & ND & $\mathrm{ND}$ \\
\hline Tween 40 & + & - & ND & $\mathrm{ND}$ & + \\
\hline Tween 60 & + & - & ND & ND & ND \\
\hline Tween 80 & - & - & ND & + & + \\
\hline Gelatin liquefaction & - & - & - & $\mathrm{W}$ & - \\
\hline \multicolumn{6}{|l|}{ Utilization of: } \\
\hline Glucose & + & - & + & - & - \\
\hline Fructose & - & - & + & - & - \\
\hline Mannose & - & - & + & - & - \\
\hline D-Ribose & - & - & + & - & - \\
\hline Sucrose & + & - & + & - & - \\
\hline Maltose & + & - & ND & - & - \\
\hline DNA $\mathrm{G}+\mathrm{C}$ content $(\mathrm{mol} \%)$ & $63 \cdot 2$ & $61 \cdot 9$ & $59 \cdot 8$ & $63 \cdot 3$ & $66 \cdot 6$ \\
\hline
\end{tabular}

$\mathrm{ABH} 32^{\mathrm{T}}$, strain $\mathrm{AX}-7^{\mathrm{T}}$ and other members of the genus Haloterrigena are listed in Table 1.

Polar lipid analysis indicated that both strain $\mathrm{ABH} 32^{\mathrm{T}}$ and strain $\mathrm{AX}-7^{\mathrm{T}}$ contained $\mathrm{C}_{20} \mathrm{C}_{20}$ and $\mathrm{C}_{20} \mathrm{C}_{25}$ derivatives of phosphatidylglycerol, phosphatidylglycerol phosphate methyl ester and bis-sulfated diglycosyl diether (see the thinlayer chromatograms available as Supplementary Figs S1 and S2 in IJSEM Online). The DNA G $+\mathrm{C}$ contents (Marmur \& Doty, 1962) of strain $\mathrm{ABH} 32^{\mathrm{T}}$ and strain $\mathrm{AX}-7^{\mathrm{T}}$ were $63 \cdot 2$ and $61 \cdot 9 \mathrm{~mol} \%$, respectively.

The 16S rRNA gene sequence similarity between strain $\mathrm{ABH} 32^{\mathrm{T}}$ and strain $\mathrm{AX}-7^{\mathrm{T}}$ was $94 \cdot 0 \%$. Phylogenetic analysis based on 16S rRNA gene similarities showed that strains $\mathrm{AX}-7^{\mathrm{T}}$ and $\mathrm{ABH} 32^{\mathrm{T}}$ are closely related to Htg. thermotolerans PRS $^{\mathrm{T}}(97 \cdot 0$ and $95 \cdot 4 \%$ similarity, respectively), Htg. saccharevitans $\mathrm{AB} 14^{\mathrm{T}}(96 \cdot 2$ and $94 \cdot 7 \%)$, Htg. turkmenica VKM B- $1734^{\mathrm{T}}(96 \cdot 0$ and $93.9 \%)$, Natrinema pallidum NCIMB $777^{\mathrm{T}}(96 \cdot 4$ and $95 \cdot 1 \%)$, Natrinema versiforme $\mathrm{XF} 10^{\mathrm{T}}(96 \cdot 2$ and $95 \cdot 3 \%)$, Natrinema pellirubrum NCIMB $786^{\mathrm{T}}(96 \cdot 0$ and $94 \cdot 7 \%)$ and Natrinema altunense $\mathrm{AJ}^{\mathrm{T}}(96 \cdot 0$ and $94.6 \%)$. A phylogenetic tree constructed on the basis of the $16 \mathrm{~S}$ rRNA gene showed that neither strain $\mathrm{ABH} 32^{\mathrm{T}}$ nor strain $\mathrm{AX}-7^{\mathrm{T}}$ clustered with Natrinema; they formed a loose group with other members of the genus Haloterrigena (Fig. 1). As strains $\mathrm{ABH} 32^{\mathrm{T}}$ and $\mathrm{AX}-7^{\mathrm{T}}$ contain bis-sulfated diglycosyl diether, a polar lipid characteristic of the genus Haloterrigena, we concluded that these strains should be classified within the genus Haloterrigena.

Levels of DNA-DNA relatedness was determined as described by De Ley et al. (1970) as modified by Huß et al. (1983). The DNA-DNA relatedness values for strain $\mathrm{ABH} 32^{\mathrm{T}}$ and strain $\mathrm{AX}-7^{\mathrm{T}}$ with respect to Htg. turkmenica JCM $8891^{\mathrm{T}}$, Htg. thermotolerans CGMCC $1.3709^{\mathrm{T}}$ and Htg. saccharevitans CGMCC $1.3730^{\mathrm{T}}$ were $43 \cdot 1,38 \cdot 2,40 \cdot 3 \%$ and $42 \cdot 5,45.9$ and $43.0 \%$, respectively. The DNA-DNA relatedness between strain $\mathrm{ABH} 32^{\mathrm{T}}$ and strain $\mathrm{AX}-7^{\mathrm{T}}$ was $32 \cdot 3 \%$.

On the basis of the phenotypic and genotypic data, it is concluded that strain $\mathrm{ABH} 32^{\mathrm{T}}$ and strain $\mathrm{AX}-\mathrm{7}^{\mathrm{T}}$ represent two novel species of the genus Haloterrigena, for which the names Haloterrigena longa sp. nov. and Haloterrigena limicola sp. nov., respectively, are proposed.

\section{Description of Haloterrigena longa sp. nov.}

Haloterrigena longa (lon'ga. L. fem. adj. longa long, referring to the production of long rods in liquid medium).

Cells are non-motile, rod-shaped $(0 \cdot 5-0 \cdot 6 \times 2 \cdot 8-11 \mu \mathrm{m})$ and Gram-negative. Colonies on agar plates containing $3 \cdot 1 \mathrm{M} \mathrm{NaCl}$ are red, elevated and round. Chemo-organotrophic and aerobic. Growth occurs at $\mathrm{NaCl}$ concentrations of $1 \cdot 7-5 \cdot 1 \mathrm{M}$, at $\mathrm{Mg}^{2+}$ concentrations of $0-1 \cdot 0 \mathrm{M}$, at $\mathrm{pH}$ values in the range $6 \cdot 5-9 \cdot 0$ and at temperatures of 30 $56{ }^{\circ} \mathrm{C}$. The optimal $\mathrm{NaCl}$ and $\mathrm{Mg}^{2+}$ concentrations for growth are $3 \cdot 1 \mathrm{M}$ and $0 \cdot 1 \mathrm{M}$, respectively. Optimal $\mathrm{pH}$ and 


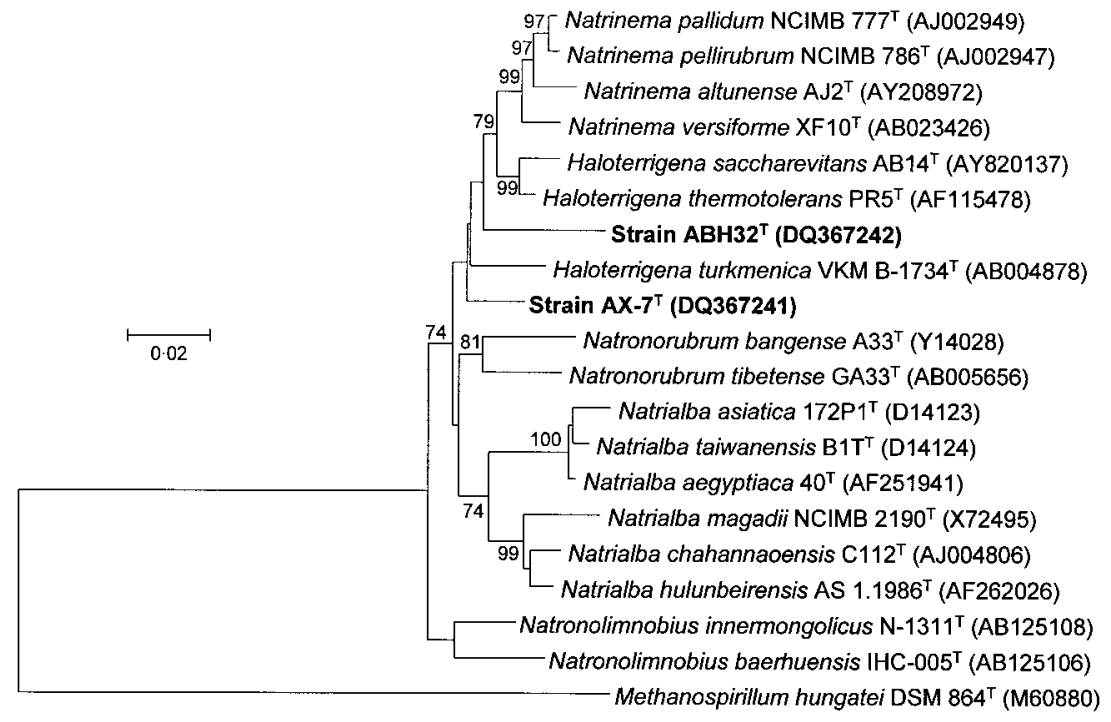

Fig. 1. Phylogenetic tree, based on $16 \mathrm{~S}$ rRNA gene sequences, showing the relationship between the members of the genus Haloterrigena and surrounding genera within the family Halobacteriaceae. The tree was constructed using MEGA, version 3.1 (Kumar et al., 2004). Bootstrap values (\%) are based on 1000 replicates and are shown for branches with more than $70 \%$ bootstrap support. Bar, 0.02 expected changes per site. temperature values are $7 \cdot 0-7 \cdot 5$ and $41-45^{\circ} \mathrm{C}$, respectively. Catalase- and oxidase-positive. Anaerobic growth with nitrate, arginine or DMSO does not occur. Nitrate reduction to nitrite is not observed. $\mathrm{H}_{2} \mathrm{~S}$ is produced from $\mathrm{Na}_{2} \mathrm{~S}_{2} \mathrm{O}_{3}$. Positive for indole formation. Tweens 20, 40 and 60 are hydrolysed but Tween 80 is not. Negative for caseinase, amylase and gelatinase. The following substrates are utilized as carbon sources: glucose, sucrose, maltose, pyruvate and acetate. Fructose, sorbose, xylose, galactose, mannose, D-ribose, lactose, mannitol and sorbitol are not utilized as carbon sources. Acid is produced in unbuffered medium from glucose and sucrose. Sensitive to rifampicin ( $5 \mu \mathrm{g}$ per disc) and novobiocin ( $30 \mu \mathrm{g}$ per disc). Resistant to the following antibiotics ( $\mu \mathrm{g}$ per disc, unless otherwise indicated): erythromycin (15), neomycin (30), chloramphenicol (30), ampicillin (10), norfloxacin (10), ciprofloxacin (5), streptomycin (10), kanamycin (30), tetracycline (30), vancomycin (30), bacitracin (0.04 IU per disc) and penicillin $\mathrm{G}$ (10 IU per disc). The major polar lipids are the $\mathrm{C}_{20} \mathrm{C}_{20}$ and $\mathrm{C}_{20} \mathrm{C}_{25}$ derivatives of phosphatidylglycerol, phosphatidylglycerol phosphate methyl ester and $\mathrm{S}_{2}$-DGD. The DNA G $+\mathrm{C}$ content of the type strain is $63 \cdot 2 \mathrm{~mol} \%$ $\left(T_{\mathrm{m}}\right)$.

The type strain, strain $\mathrm{ABH} 32^{\mathrm{T}}$ ( = CGMCC $1.5334^{\mathrm{T}}=\mathrm{JCM}$ $13562^{\mathrm{T}}$ ), was isolated from Aibi salt lake in Xin-Jiang, China.

\section{Description of Haloterrigena limicola sp. nov.}

Haloterrigena limicola (li.mi'co.la. L. n. limus mud; L. suff. - cola from L. n. incola dweller; N.L. masc. or fem. n. limicola mud-dweller).

Cells are motile, rod-shaped $(0 \cdot 6-0 \cdot 8 \times 1 \cdot 8-3 \cdot 6 \mu \mathrm{m})$ and Gram-negative. Colonies on agar plates containing $2 \cdot 6 \mathrm{M}$ $\mathrm{NaCl}$ are red, elevated and round. Chemo-organotrophic and aerobic. Growth occurs at $\mathrm{NaCl}$ concentrations of $1 \cdot 7-5 \cdot 1 \mathrm{M}$, at $\mathrm{Mg}^{2+}$ concentrations of $0 \cdot 005-0 \cdot 7 \mathrm{M}$, at $\mathrm{pH}$ values in the range $6 \cdot 5-9 \cdot 0$ and at temperatures of $30-61{ }^{\circ} \mathrm{C}$.
Optimal $\mathrm{NaCl}$ concentration, $\mathrm{Mg}^{2+}$ concentration, $\mathrm{pH}$ and temperature for growth are $3 \cdot 1 \mathrm{M}, 0.05 \mathrm{M}, \mathrm{pH} 7.0$ and $45-50{ }^{\circ} \mathrm{C}$, respectively. Catalase- and oxidase-positive. Anaerobic growth with nitrate, arginine or DMSO does not occur. Nitrate reduction to nitrite is observed. $\mathrm{H}_{2} \mathrm{~S}$ is produced from $\mathrm{Na}_{2} \mathrm{~S}_{2} \mathrm{O}_{3}$. Negative for indole formation. Tween 20 is hydrolysed, but Tweens 40,60 and 80 are not. Negative for caseinase, amylase and gelatinase. Glucose, sucrose, maltose, fructose, sorbose, xylose, galactose, mannose, D-ribose, lactose, mannitol and sorbitol are not utilized as carbon sources. Pyruvate and acetate are utilized for growth. Sensitive to rifampicin ( $5 \mu \mathrm{g}$ per disc) and novobiocin $(30 \mu \mathrm{g}$ per disc). Resistant to the following antibiotics ( $\mu \mathrm{g}$ per disc, unless otherwise indicated): erythromycin (15), neomycin (30), chloramphenicol (30), ampicillin (10), norfloxacin (10), ciprofloxacin (5), streptomycin (10), kanamycin (30), tetracycline (30), vancomycin (30), bacitracin (0.04 IU per disc) and penicillin G (10 IU per disc). The major polar lipids are the $\mathrm{C}_{20} \mathrm{C}_{20}$ and $\mathrm{C}_{20} \mathrm{C}_{25}$ derivatives of phosphatidylglycerol, phosphatidylglycerol phosphate methyl ester and $S_{2}$-DGD. The DNA $G+C$ content of the type strain is $61.9 \mathrm{~mol} \%\left(T_{\mathrm{m}}\right)$.

The type strain, strain AX-7 ${ }^{\mathrm{T}}$ (=CGMCC $1.5333^{\mathrm{T}}=\mathrm{JCM}$ $13563^{\mathrm{T}}$ ), was isolated from Aibi salt lake in Xin-Jiang, China.

\section{Acknowledgements}

This work was supported by grants from the Ministry of Science and Technology (2004CB719601) and from the Chinese Academy of Sciences (KJCX1-SW-07).

\section{References}

Cui, H.-L., Yang, Y., Tothy, D., Zhou, P.-J. \& Liu, S.-J. (2006). Biodiversity of halophilic Archaea isolated from two salt lakes in Xin-Jiang region of China. Acta Microbiol Sin 46, 171-176. 
De Ley, J., Cattoir, H. \& Reynaerts, A. (1970). The quantitative measurement of DNA hybridization from renaturation rates. Eur J Biochem 12, 133-142.

Feng, J., Zhou, P.-J. \& Liu, S.-J. (2004). Halorubrum xinjiangense sp. nov., a novel halophile isolated from saline lakes in China. Int J Syst Evol Microbiol 54, 1789-1791.

Feng, J., Zhou, P.-J., Liu, S.-J. \& Warren-Rhodes, K. (2005). Halorubrum alkaliphilum sp. nov., a novel haloalkaliphile isolated from a soda lake in Xin-Jiang, China. Int J Syst Evol Microbiol 55, 149-152.

Huß, V. A. R., Festl, H. \& Schleifer, K. H. (1983). Studies on the spectrometric determination of DNA hybridization from renaturation rates. Syst Appl Microbiol 4, 184-192.

Kumar, S., Tamura, K. \& Nei, M. (2004). MEGA3: integrated software for molecular evolutionary genetics analysis and sequence alignment. Brief Bioinform 5, 150-163.

Marmur, J. \& Doty, P. (1962). Determination of the base composition of deoxyribonucleic acid from its thermal denaturation temperature. J Mol Biol 4, 109-118.

McGenity, T. J., Gemmell, R. T. \& Grant, W. D. (1998). Proposal of a new halobacterial genus Natrinema gen. nov., with two species Natrinema pellirubrum nom. nov. and Natrinema pallidum nom. nov. Int J Syst Bacteriol 48, 1187-1196.
Montalvo-Rodríguez, R., Lopez-Garriga, J., Vreeland, R. H., Oren, A., Ventosa, A. \& Kamekura, M. (2000). Haloterrigena thermotolerans sp. nov., a halophilic archaeon from Puerto Rico. Int J Syst Evol Microbiol 50, 1065-1071.

Oren, A., Ventosa, A. \& Grant, W. D. (1997). Proposal of minimal standards for the description of new taxa in the order Halobacteriales. Int J Syst Bacteriol 47, 233-238.

Tindall, B. J. (2003). Taxonomic problems arising in the genera Haloterrigena and Natrinema. Int J Syst Evol Microbiol 53, 1697-1698.

Ventosa, A., Gutierrez, M. C., Kamekura, M. \& Dyall-Smith, M. L. (1999). Proposal to transfer Halococcus turkmenicus, Halobacterium trapanicum JCM 9743 and strain GSL-11 to Haloterrigena turkmenica gen. nov., comb. nov. Int J Syst Bacteriol 49, 131-136.

Xin, H.-W., Itoh, T., Zhou, P.-J., Suzuki, K., Kamekura, M. \& Nakase, T. (2000). Natrinema versiforme sp. nov., an extremely halophilic archaeon from Aibi salt lake, Xin-Jiang, China. Int J Syst Evol Microbiol 50, 1297-1303.

Xu, X.-W., Liu, S.-J., Tothy, D., Oren, A., Wu, M. \& Zhou, P.-J. (2005). Haloterrigena saccharevitans sp. nov., an extremely halophilic archaeon from Xin-Jiang, China. Int J Syst Evol Microbiol 55, 2539-2542.

Zvyagintseva, I. S. \& Tarasov, A. L. (1987). Extreme halophilic bacteria from saline soils. Microbiology (English translation of Mikrobiologiia) 56, 664-669. 